Original article

\title{
Elisa testing of brain and spleen homogenates for transmissible spongiform encephalopathy / scrapie of sheep
}

\author{
Hendrik De Bosschere*, Stefan RoELS, Emmanuel VANOPDENBOSCH
}

\author{
Department of Biocontrol, Veterinary and Agrochemical Research Centre (VAR), \\ National Reference Laboratory for Veterinary TSE (Belgium and Luxemburg), Groeselenberg 99, \\ B-1180 Brussels (Ukkel), Belgium
}

(Received 16 March 2004; accepted 11 February 2005)

\begin{abstract}
A diagnosis of TSE / scrapie in sheep is based on a positive ELISA of the obex, which is confirmed by confirmation tests, such as histopathology, immunohistochemistry, electronmicroscopy (scrapie associated fibrils (SAF)) and Western blot. However, preclinical scrapie cases may only be detected 3 months before the onset of symptoms based on a positive ELISA of the obex, while a 1.5 year preclinical diagnosis can be obtained based on a positive immunostaining of the lymphoid tissue (tonsil, spleen, lymph node, third eyelid) with other tests on the brain tissue still being negative. The brain tissue and spleen of positive (clinical and preclinical) and negative scrapie sheep were examined with immunohistochemistry, ELISA and Western blot. In most cases, all tests were consistent for the same tissue. It can be concluded that with minor adaptations of the ELISA technique, ELISA on the lymphoid tissue of sheep are as reliable, easier and quicker to perform than immunohistochemistry. This can be of importance in epidemiosurveillance, i.e. the detection of infected (clinical cases and preclinical cases), and the eradication and spread of the disorder within the population.
\end{abstract}

sheep / scrapie / ELISA / brain / spleen

Résumé - Utilisation de la technique ELISA sur des homogénats de cerveau et de rate pour diagnostiquer l'encéphalopathie spongiforme transmissible / tremblante chez les moutons. Le diagnostic de la tremblante chez les moutons est fondé sur un test ELISA positif, pratiqué sur des échantillons d'obex, suivi d'un test de confirmation par histopathologie, immunohistochimie, microscopie électronique (protéines fibrillaires associées à la tremblante (SAFs)) ou Western-blot. Alors que le diagnostic préclinique de tremblante ne peut être posé que 3 mois avant le début des premiers symptômes avec les tests de type ELISA, il existe un dépistage précoce qui peut être réalisé un an et demi avant l'apparition des premiers signes cliniques. Ce dépistage est basé sur une analyse immunohistochimique des tissus lymphoïdes (amygdale, rate, ganglion, troisième paupière) et donne des résultats positifs alors que les tests classiques sont négatifs sur le tissu cérébral. Une étude a été menée afin d'examiner et de comparer les résultats obtenus par immunohistochimie, ELISA et Western-blot sur le tissu cérébral et la rate de moutons diagnostiqués positifs (cliniques et

* Corresponding author: hedeb@var.fgov.be 
précliniques) ou négatifs à la tremblante. Dans la plupart des cas, les différents tests réalisés sur un même tissu ont donnés des résultats concordants. La technique ELISA et son application aux tissus lymphoïdes de moutons a donc été aussi fiable, plus facile et plus rapide que l'immunohistochimie. Ceci peut être d'importance pour l'épidémiosurveillance de la tremblante, c'est-à-dire la détection des moutons infectés (cas cliniques et précliniques), dans le but d'éradiquer la tremblante chez les ovins.

mouton / tremblante / ELISA / cerveau / rate

\section{INTRODUCTION}

Scrapie is a fatal transmissible spongiform encephalopathy caused by prions. Prion diseases also include Creutzfeldt-Jakob disease (CJD) in humans, bovine spongiform encephalopathy (BSE) in cattle and chronic wasting disease (CWD) in wild ruminants. Typical features of these diseases are a long incubation period and the gradual vacuolation of brain neurons and neuropil. The pathogenesis of the disease is believed to be due to the conversion of the normal proteasesensitive prion protein, $\operatorname{PrP}^{\mathrm{c}}$, into a partly protease-resistant isoform, $\mathrm{PrPsc}^{\mathrm{sc}}$, which accumulates progressively in the central nervous system of the affected animals [4, 17].

Oral infection is likely to be the natural route of scrapie infection in sheep [8]. The pathogenesis of natural scrapie could be discerned in three phases [24]. The first phase is the invasion of the gut associated lymphoid tissue (GALT) [10], such as palatine tonsils, Peyers patches and enteric draining lymph nodes. It is believed that via M-cells, the scrapie agent gains access to the underlying tissues [12]. Then, the scrapie agent is carried via dendritic cells or macrophages to the germinal centres of the underlying lymphoid follicles [1]. The PrPsc containing and free-ranging cells present in the cortical and paracortical sinuses of the follicles could be responsible for dissemination of the scrapie agent. When these cells gain access to the efferent lymph and subsequently the blood stream they could produce the second stage of the scrapie pathogenesis, which is the dissemination of the scrapie agent to non-GALT-associated lymphoid tissues. The third stage of scrapie pathogenesis is neuroinvasion. Van Keulen et al. [24] have found the enteric nervous system (ENS) as the first neural tissue to be infected by the scrapie agent. The close association between the Peyer patches of the gut and the submucosal and myenteric plexus of the enteric nervous system could facilitate infection of the ENS. From there, the scrapie agent follows parasympathetic and sympathetic efferent neuronal pathways to finally gain access to the brain and via the ganglion mesentericum craniale/ coeliacum to the spinal cord. In the brain, the scrapie agent spreads in both an ascending and descending direction. However, other routes of neuroinvasion are not precluded. It is also theoretically possible that the scrapie agent travels to the CNS through other peripheral nerve endings originating from infected non-GALT lymphoid tissues or through haematogenic spread of the scrapie agent during a possible "viremic" phase. However, some less sensitive PrP genotypes show a scrapie infection of the central nervous system without prior invasion of the lymphoid tissues comparable to the BSE pathogenesis in cattle [24].

Roels et al. [20] demonstrated that clinically affected and scrapie positive sheep showed histopathological lesions in the brainstem and positivity of the obex and tonsils on immunohistochemistry (IHC). However, there were also some sheep with no clinical symptoms or histopathological lesions in the brainstem, but with a positive reaction of the tonsils and obex on immunohistochemistry or a positive immunohistochemical reaction of the tonsils alone. Similar findings were also observed by Grassi et al. [7] and Schreuder et al. [19]. Grassi and colleges [7] diagnosed preclinical cases 3 months before the onset of 
clinical symptoms using an ELISA of the obex. Schreuder et al. [19] detected preclinical cases more than one and a half years before clinical symptoms normally appear with the IHC of tonsil biopsies of live animals. From a diagnostic and epidemiological point of view, it may be interesting not only to detect the clinically affected scrapie sheep but also the preclinically affected scrapie sheep. IHC is a practical and sensitive diagnostic method that can be performed in every histopathological laboratory. However, the protocol for IHC requires a minimum of 3 to 5 days of preparation time before specimens are ready for microscopic evaluation, whereas ELISA (TeSeE kit Bio-Rad, Nazareth, Belguim) requires only 5 hours before the results are available [9].

The present paper describes the possibility for the use of the sheep's spleen in epidemiosurveillance via a rapid testing protocol (EC regulation 999/2001).

\section{MATERIALS AND METHODS}

In Belgium, since April 2002, all dead or slaughtered sheep older than 18 months are tested with a rapid test (TeSeE kit, Bio-Rad, Nazareth, Belgium) [5,6] for scrapie through the active TSE surveillance programme $[16,21]$. This rapid test is used for the diagnosis of bovine spongiform encephalopathy (BSE) in bovine brain tissues [11], but is also suitable for the diagnosis of scrapie in sheep, since both the monoclonal antibodies used in this test recognise the ovine PrP protein [2]. For the ELISA test, a brain tissue of a sample of $350 \pm 40 \mathrm{mg}$ of the obex region is required [20]. Instead, only $200 \pm$ $25 \mathrm{mg}$ of spleen tissue is necessary [9] for the same test. Spleen tissue and lymphoid tissue in general are more fibrous than brain tissue, therefore a slight modification of the grinding procedure is implemented, such as the addition of a macro bead in the grinding tube (Fig. 1) of the TeSeE purification phase and 2 cycles of $45 \mathrm{~s}$ agitation in the homogeniser instead of one cycle for brain tissue. All the other steps of the purification proc-

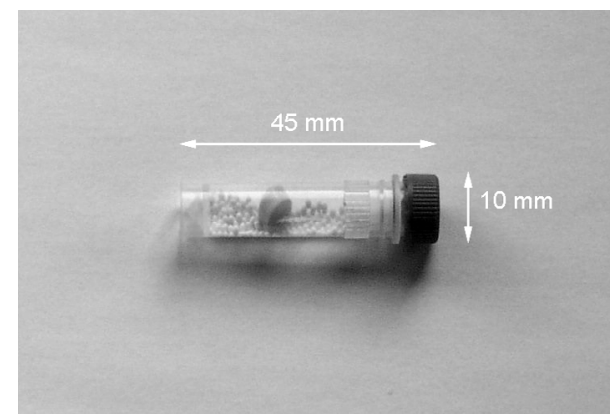

Figure 1. Photograph of the grinding tube with small ceramic beads (for brain tissue) and one large (in the middle of the tube) macro bead (for lymphoid tissue) in a 5\% glucose solution.

ess are unchanged as well as the detection phase.

The results of the ELISA, immunohistochemistry and Western blot of the brain and spleen homogenates of the same sheep were compared.

The brain tissue was routinely further examined for TSE / scrapie with the classical (confirmation) tests: SAF, histopathology, immunohistochemistry (IHC) [25] and Western blot (Ovine WB using antibodies SAF60 and BAR226; Bio-Rad, Marnes-laCoquette, France). A positive scrapie diagnosis is based on minimum one positive confirmation test (Federaal Agentschap voor de Veiligheid van de Voedselketen Procedure P012: Behandeling van een verdacht TSE-monster-1 oktober 2003). Another lymphoid tissue (tonsil and mandibular lymph node) was tested immunohistochemically if present. The IHC technique using the antibody R524-7 (rabbit anti-PrP-peptide serum, kindly provided by CIDC Lelystad, The Netherlands) and 2G11 (Institut Pourquier, Montpellier, France) is described by van Keulen et al. [22]. A positive or negative IHC is based on respectively a positive or negative IHC with both antibodies. If the IHC of both antibodies do not match, the final conclusion of IHC is 
based upon the results of the other tests on the spleen.

Non-coagulated blood samples of all sheep were genotyped using denaturing gradient gel electrophoresis (DGGE) [3].

\section{RESULTS}

The data of the different tests (including ELISA and IHC) performed on the brain and spleen homogenates of the different sheep can be found in Table I.

The first set of samples (samples 1-24) show a positive ELISA and IHC of the obex and spleen of the same sheep. The WB was negative in only 3 cases, but the optical density of the ELISA of these cases was low. All sheep had at least one VRQ allele of the PrP gene.

The following three samples (samples 2527) show a positive ELISA and IHC of the obex, but a negative ELISA of the spleen of the same sheep. However, in one case (sample 27) the WB of the spleen was positive and in two cases (samples 26, 27) the IHC of the spleen was also positive.

The third set of samples (samples 28-30) had a negative ELISA and IHC of the obex, but a positive ELISA and IHC of the spleen. In only one case (sample 28) another confirmation test (WB) of the obex was positive. All spleen WB were positive.

Samples 31 and 32 are examples of negative cases. All tests performed (including ELISA and IHC of the obex and spleen) were negative.

The fifth set of the samples (samples 33 38) had a negative ELISA of the obex and spleen. The IHC of the obex and spleen with antibody 2G11 was negative, while a scattered slightly positive signal on the IHC of the spleen was observed using the R524-7 antibody. Nevertheless, the IHC of the spleen was considered negative since the WB and ELISA of the spleen (and obex) were all negative.

\section{DISCUSSION}

Based on the data reported in this study, the ELISA of the sheep's spleen is also an excellent and effective diagnostic tool for scrapie screening. IHC and ELISA appear to be equally sensitive for the detection of scrapie. Moreover, likely neither test is completely accurate in early cases with minimal $\mathrm{PrP}^{\mathrm{sc}}$ deposition. It must be stressed that the process of full validation of all of these diagnostic methods for TSE has been restrained by the lack of a true gold standard and the consequent need to apply standards of comparison based on relatively small studies. There is therefore a continuing need for the publication of larger scale studies of assay performance. Caution must be exercised in the comparative interpretation of tests applied to apparently healthy animals since different tests may vary in their sensitivities relative to the stage of incubation and pathogenesis of the disease [13]. This may explain some discrepancies (samples 3, 4, 18, 26-28 and 33-38) detected in the table.

Three samples of the first set had a negative WB of the obex, however all other tests on the obex and spleen were positive. The ELISA's optical densities of the obex of these sheep were rather low (slightly above the cut-off value). Low optical densities correspond with a limited presence of $\mathrm{PrP}^{\mathrm{sc}}$ deposits, while high optical densities correspond with large amounts of $\mathrm{PrP}^{\mathrm{sc}}$ [5]. The presence of $\mathrm{PrP}^{\mathrm{sc}}$ may have been too little for a positive WB.

The second set of samples were positively diagnosed scrapie cases based on positive results of brain tissue, however all three spleen ELISA were all negative (optical densities slightly below the cut-off value), while one spleen WB (sample 27) was slightly positive and two IHC (samples 26 , 27) also showed a weak positive staining. The reason for this ELISA discrepancy may be selection and subsampling of spleen tissue, which may influence the outcome of ELISA, WB and IHC. However, another route of neuroinvasion in these cases cannot 
Table I. Data of ELISA and IHC of the brain and spleen homogenates of sheep.

\begin{tabular}{|c|c|c|c|c|c|c|c|c|c|}
\hline $\mathrm{TSE}^{\circ}$ & $\begin{array}{c}\text { ELISA } \\
\text { Brain }\end{array}$ & $\begin{array}{c}\text { WB } \\
\text { Brain }\end{array}$ & $\begin{array}{c}\text { IHC } \\
\text { Brain }\end{array}$ & $\begin{array}{l}\text { SAF } \\
\text { Brain }\end{array}$ & $\begin{array}{c}\text { HISTO } \\
\text { Brain }\end{array}$ & $\begin{array}{c}\text { Elisa } \\
\text { Spleen }\end{array}$ & $\begin{array}{c}\text { WB } \\
\text { Spleen }\end{array}$ & $\begin{array}{c}\text { IHC } \\
\text { Spleen }\end{array}$ & Genotype \\
\hline 1 & + & + & + & - & + & + & + & + & ARH/VRQ \\
\hline 2 & + & + & + & - & + & + & + & + & ARH/VRQ \\
\hline 3 & + & - & + & - & - & + & + & + & ARQ/VRQ \\
\hline 4 & + & - & + & - & + & + & + & + & ARQ/VRQ \\
\hline 5 & + & + & + & - & + & + & + & + & $\mathrm{ARQ} / \mathrm{VRQ}$ \\
\hline 6 & + & + & + & - & + & + & + & + & VRQ/VRQ \\
\hline 7 & + & + & + & - & + & + & + & + & $\mathrm{ARQ} / \mathrm{VRQ}$ \\
\hline 8 & + & + & + & - & + & + & + & + & ARH/VRQ \\
\hline 9 & + & + & + & - & + & + & + & + & $\mathrm{ARQ} / \mathrm{VRQ}$ \\
\hline 10 & + & + & + & - & - & + & + & + & ARH/VRQ \\
\hline 11 & + & + & + & - & + & + & + & + & ARH/VRQ \\
\hline 12 & + & + & + & - & - & + & + & + & ARH/VRQ \\
\hline 13 & + & + & + & + & - & + & + & + & VRQ/VRQ \\
\hline 14 & + & + & + & + & + & + & + & + & ARR/VRQ \\
\hline 15 & + & + & + & + & + & + & + & + & ARH/VRQ \\
\hline 16 & + & + & + & + & + & + & + & + & $\mathrm{ARQ} / \mathrm{VRQ}$ \\
\hline 17 & + & + & + & + & + & + & + & + & ARQ/VRQ \\
\hline 18 & + & - & + & + & - & + & + & + & ARQ/VRQ \\
\hline 19 & + & + & + & + & + & + & + & + & ARQ/VRQ \\
\hline 20 & + & + & + & + & + & + & + & + & ARR/VRQ \\
\hline 21 & + & + & + & + & - & + & + & + & VRQ/VRQ \\
\hline 22 & + & + & + & + & + & + & + & + & VRQ/VRQ \\
\hline 23 & + & + & + & - & + & + & + & + & $\mathrm{ARQ} / \mathrm{VRQ}$ \\
\hline 24 & + & + & + & + & - & + & + & + & ARR/VRQ \\
\hline 25 & + & - & + & - & + & - & - & - & $\mathrm{ARQ} / \mathrm{ARH}$ \\
\hline 26 & + & + & + & - & + & - & - & + & ARQ/VRQ \\
\hline 27 & + & + & + & + & + & - & + & + & ARQ/VRQ \\
\hline 28 & - & + & - & - & - & + & + & + & ARQ/VRQ \\
\hline 29 & - & - & - & - & - & + & + & + & ARQ/VRQ \\
\hline 30 & - & - & - & - & - & + & + & + & ARQ/VRQ \\
\hline 31 & - & - & - & - & - & - & - & - & ARR/VRQ \\
\hline 32 & - & - & - & - & - & - & - & - & ARR/ARH \\
\hline 33 & - & - & - & - & - & - & - & $-*$ & ARQ/VRQ \\
\hline 34 & - & - & - & - & - & - & - & $-*$ & ARQ/ARQ \\
\hline 35 & - & - & - & - & - & - & - & $-*$ & ARQ/ARQ \\
\hline 36 & - & - & - & - & - & - & - & $-*$ & ARR/ARQ \\
\hline 37 & - & - & - & - & - & - & - & $-*$ & $\mathrm{ARQ} / \mathrm{ARH}$ \\
\hline 38 & - & - & - & - & - & - & - & -* $^{*}$ & ARR/ARQ \\
\hline
\end{tabular}

WB: Western blot, IHC: Immunohistochemistry, SAF: Electronmicroscopy, HISTO: Histopathology. -*: Final conclusion of IHC is based upon the other test results of the spleen, since IHC tested slightly positive using the antibody R524-7, but negative using the antibody 2 G11. All other tests of the spleen (and also obex) were negative. 
be precluded, with less $\mathrm{PrP}^{\mathrm{sc}}$ present in the lymphoid tissues than expected.

The third set of samples is an example of three preclinical cases: negative at the level of the brain but positive at the level of the spleen. Similar results were also observed by Hibler et al. [9] in wild cervids. $\mathrm{PrP}^{\mathrm{Sc}}$ detection by immunohistochemistry is considered to have potential for the preclinical diagnosis of scrapie in sheep using tonsillar [19] or nictitating membrane $[14,15]$ lymphoid tissue biopsies up to one year and a half before the onset of clinical symptoms. The present study shows that ELISA on lymphoid tissue (spleen in this case) is a suitable alternative for detecting preclinical cases.

However, it is assumed that IHC is as sensitive as Western blotting for detecting $\mathrm{PrP}^{\mathrm{Sc}}$ [18]. Although, in the fifth set of samples, a scattered slight "background staining", difficult to differentiate from specific staining was observed using the antibody R524-7, while the IHC using the antibody $2 \mathrm{G} 11$ was negative as well as in all other tests (WB and ELISA). This may be due to aspecific reactions related to the polyclonal nature of the antibody used (R524-7), since this was not noticed on the slides using the monoclonal antibody (2G11), or to the young age of the animals.

In the present study, the VRQ allele was much more present in the genotypes of the scrapie positive cases (clinical and preclinical) compared to the genotypes of the negative cases. Some sheep with a resistance allele such as the ARR allele were found to be positive with all the methods (samples 14,20 and 24) in the spleen. This was in contrast to published data [22, 23] suggesting (from a very small number of cases) that the ARR allele might be associated with the absence of abnormal PrP in peripheral tissues. Also some susceptible genotypes did not show detectable PrP in the spleen with certain tests, despite its presence in the brain (samples 25-28). This was also in contrast with the general knowledge about the pathogenesis of the infection [23, 24]. This suggests that the involvement of the spleen can well be bypassed and that the analysis of the spleen could not replace that of the brain for the diagnosis of the disease.

In conclusion, ELISA on the spleen seems to be an excellent and effective diagnostic tool for rapid screening of the spleen or other lymphoid tissue from sheep for the presence of TSE / scrapie (as similar as CWD in wild cervids [9]) next to IHC, especially for the detection of preclinical cases of scrapie (ante-mortem or postmortem). Nevertheless, it is always recommended to use at least two different tests, for example a rapid test (ELISA), which is afterwards confirmed by a more classical test such as IHC or WB on neural and lymphoid tissue. It will be an asset in limiting the spread of scrapie throughout the sheep population.

\section{ACKNOWLEDGEMENTS}

The staff of the department of Biocontrol is thanked for its technical assistance.

\section{REFERENCES}

[1] Aguzzi A., Peripheral prion pursuit, J. Clin. Invest. 108 (2001) 661-662.

[2] Andréoletti O., Berthon P., Marc D., Sarradin P., Grosclaude J., Van Keulen L., Schelcher F., Elsen J.-M., Lantier F., Early accumulation of $\operatorname{PrP}(\mathrm{Sc})$ in gut-associated lymphoid and nervous tissues of susceptible sheep from a Romanov flock with natural scrapie, J. Gen. Virol. 81 (2000) 3115-3126.

[3] Bossers A., Schreuder B.E.C., Muileman I.H., Belt P.B.G.M., Smits M.A., PrP genotype contributes to determining survival times of sheep with natural scrapie, J. Gen. Virol. 77 (1996) 2669-2673.

[4] Büeler H., Aguzzi A., Sailer A., Greiner R.A., Autenried P., Aguet M., Weissmann C., Mice devoid of PrP are resistant to scrapie, Cell 73 (1993) 1339-1347.

[5] De Becker D., Roels S., Vanopdenbosch E., BSE onderzoek: opsporen van PrPres door middel van de BIO-RAD Platelia BSE-kit. Vl. Diergeneesk, Tijdschr. 69 (2000) 382-384. 
[6] De Bosschere H., Roels S., Vanopdenbosch E., Semi-quantitative use of the Bio-Rad TeSeE kit, Life Sci. InFocus 6 (2005) 7-9.

[7] Grassi J., Comoy E., Simon S., Creminon C., Frobert Y., Trapmann S., Schimmel H., Hawkins S.A., Moynagh J., Deslys J.P., Wells G.A., Rapid test for the preclinical postmortem diagnosis of BSE in central nervous system tissue, Vet. Rec. 149 (2001) 577-582.

[8] Hadlow W.J., Kennedy R.C., Race R.E., Natural infection of Suffolk sheep with scrapie virus, J. Infect. Dis. 146 (1982) 657-664.

[9] Hibler C.P., Wilson K.L., Spraker T.R., Miller M.W., Zink R.R., DeBuse L.L., Andersen E., Schweitzer D., Kennedy J.A., Baeten L.A., Smeltzer J.F., Salman M.D., Powers B.E., Field validation and assessment of an enzymelinked immuno sorbent assay for detecting chronic wasting disease in mule deer (Odocoileus hemionus), white-tailed deer (Odocoileus virginianus), and Rocky Mountain elk (Cervus, elaphus nelsoni), J. Vet. Diagn. Invest. 15 (2003) 311-319.

[10] Lezmi S., Bencsik A., Baron T., CNA42 monoclonal antibody identifies FDC as PrPsc accumulating cells in the spleen of scrapie affected sheep, Vet. Immunol. Immunop. 82 (2001) 1-8.

[11] Moynagh J., Schimmel H., Tests for BSE evaluated, Nature 400 (1999) 105.

[12] Neutra M.R., Pringault E., Kraehenbuhl J.P., Antigen sampling across epithelial barriers and induction of mucosal immune responses, Ann. Rev. Immunol. 14 (1996) 275-300.

[13] Office International des Epizooties Website, Chap. 2.3.13, Bovine spongiform encephalopathy, http://www.oie.int/eng/normes/mmanual/ A_00060.htm, 2003.

[14] O'Rourke K.I., Baszler T.V., Parish S.M., Knowles D.P., Preclinical detection of PrPSc in nictitating membrane lymphoid tissue of sheep, Vet. Rec. 142 (1998) 489-491.

[15] O'Rourke K.I., Baszler T.V., Besser T.E., Miller J.M., Cutlip R.C., Wells G.A.H., Ryder S.J., Parish S.M., Hamir A.N., Cockett N.E., Jenny A., Knowles D.P., Preclinical Diagnosis of Scrapie by Immunohistochemistry of Third Eyelid Lymphoid Tissue, J. Clin. Microbiol. 38 (2000) 3254-3259.

[16] Pastoret P.P., Gouffaux M., Saegerman C., Roels S., Dechamps P., Thiry E., Vanopdenbosch E., Le diagnostic immunologique rapide des encéphalopathies spongiformes transmissibles, Ann. Med. Vet. 145 (2001) 164-173.

[17] Prusiner S.B., Novel proteinaceous infectious particles cause scrapie, Science 216 (1982) 136-144.

[18] Schaller O., Fatzer R., Stack M., Clark J., Cooley W., Biffiger K., Egli S., Doherr M., Vandevelde M., Heim D., Oesch B., Moser M., Validation of a Western immunoblotting procedure for bovine PrPSc detection and its use as a rapid surveillance method for the diagnosis of bovine spongiform encepahlopathy (BSE), Acta Neuropathol. (Berl) 98 (1999) 437-443.

[19] Schreuder B.E.C., Van Keulen L.J.M., Vromans M.E.W., Langeveld J.P.M., Smits M.A., Tonsillar biopsy and PrPsc detection in the preclinical diagnosis of scrapie, Vet. Rec. 142 (1998) $564-568$

[20] Roels S., Vanopdenbosch E., Langeveld J.P.M., Schreuder B.E.C., Immunohistochemical evaluation of tonsillar tissue for preclinical screening of scrapie based on surveillance in Belgium, Vet. Rec. 145 (1999) 524 525.

[21] Roels S., De Meyer G., Tedik K., Foubert R., Vaonopdenbosch E., Variation of mass (volume) taken with the calibrated syringe and of the results provided by the Bio-Rad Platelia BSE test upon storage of brainstem samples at $-20{ }^{\circ} \mathrm{C}$, Anim. Res. 51 (2002) 493-499.

[22] Van Keulen L.J.M., Schreuder B.E.C., Meloen R.H., Mooijharkes G., Poelen-Van Den Berg M., Vromans M.E.W., Langeveld J., Immunohistochemical detection and localization of prion protein in brain tissue of sheep with natural scrapie, Vet. Pathol. 34 (1995) 12281231.

[23] Van Keulen L.J.M., Schreuder B.E.C., Vromans M.E.W., Langeveld J.P.M., Smits M.A., Pathogenesis of natural scrapie in sheep, Arch. Virol. (Suppl.) 16 (2000) 57-71.

[24] Van Keulen L.J.M., Vromans M.E.W., Van Zijderveld F.G., Early and late pathogenesis of natural scrapie infection in sheep, Acta Pathol. Microbiol. Immunol. Scand. 110 (2002) 23-32.

[25] Vanopdenbosch E., Dechamps P., Dufey J., Roels S., Mullier P., Hallet C., Brochier B., Costy F., Pastoret P.P., Le premier cas d'encephalopathie spongioforme bovine diagnostique en Belgique, Ann. Med. Vet. 142 (1998) 111-118. 